\title{
Nutritional challenges in older adults during the COVID-19 pandemic
}

\author{
Desafios nutricionais na saúde de idosos \\ em tempos de pandemia da COVID-19
}

\author{
Gilciane CEOLIN1 (iD) 0000-0003-0525-2867 \\ Júlia Dubois MOREIRA² (D) 0000-0002-2256-7222 \\ Bruna Cunha MENDES1 (D) 0000-0002-8554-9486 \\ Jaqueline SCHROEDER ${ }^{1}$ (D) 0000-0003-0013-3965 \\ Patricia Faria DI PIETRO2 (D) 0000-0003-1343-5049 \\ Debora Kurrle RIEGER ${ }^{2}$ (D) 0000-0002-8726-8899
}

A B S T R ACT

It has been documented that the older adults of the population are at the greatest risk of mortality due to the coronavirus disease; consequently, they could be the population most affected by the measures of social isolation and reduction of virus contagion implemented worldwide. Social isolation can expose older adults to an increased nutritional risk due to factors such as socioeconomic insecurity, which could affect food acquisition and the need for support in daily tasks and meals. The institutionalized older adults often depend on food donations, which may have reduced due the economic crisis caused by the pandemic, and the aging process itself causes changes in nutritional necessities and eating habits. In the coronavirus pandemic, nutritionists and dietitians can offer remote nutritional follow-up. Moreover, the government actions, such as the implementation of educational and social service programs, should be applied to support healthy aging and minimize exposure to nutritional risks and coronavirus disease.

Keywords: Aged. Coronavirus infection. Nutrition. Pandemics.

\footnotetext{
${ }^{1}$ Universidade Federal de Santa Catarina, Centro de Ciências da Saúde, Programa de Pós-Graduação em Nutrição. Florianópolis, SC, Brasil.

2 Universidade Federal de Santa Catarina, Centro de Ciências da Saúde, Departamento de Nutrição. Campus Universitário, R. Eng. Agronômico Andrei Cristian Ferreira, s/n., Trindade, 88040-900, Florianópolis, SC. Brasil. Correspondence to: DK RIEGER. E-mail: <deboravenske@gmail.com>.
}

\section{How to cite this article}

Ceolin G, Moreira JD, Mendes BC, Schroeder J, Di Pietro PF, Rieger DK. Nutritional challenges in older adults during the coronavirus pandemic. Rev Nutr. 2020;33:e200174. https://doi.org/10.1590/1678-9865202032e200174 


\section{RE S U M O}

Tem sido documentado que os idosos são a população de maior risco para mortalidade por COVID-19. Consequentemente, pode ser a mais afetada pelas medidas de isolamento social e de redução de contágio pelo vírus implementadas em todo o mundo. O isolamento social pode expor os idosos ao risco nutricional aumentado devido a alguns fatores, como: a insegurança socioeconômica, a qual pode afetar a aquisição de alimentos; a necessidade de apoio nas tarefas e nas refeições diárias; a possível redução de doações de alimentos para idosos institucionalizados, em virtude da crise econômica ocasionada pela pandemia; e o próprio processo do envelhecimento, que causa alterações das necessidades nutricionais e do hábito de se alimentar. Contudo, no contexto da pandemia do novo coronavírus, nutricionistas podem oferecer acompanhamento nutricional remoto. Além disso, ações governamentais, como a implementação de programas educacionais e de serviço social, devem ser aplicadas para o envelhecimento saudável e para a minimização da exposição ao risco nutricional e à COVID-19.

Palavras-chave: Idosos. Infecções por Coronavirus. Nutrição. Pandemia.

Older adults, those individuals aged 60 or over, are the most affected by Coronavirus Disease (COVID-19) worldwide, with higher admission rates in the intensive care units, frequency of adverse events, and mortality rates [1,2]. In Brazil, until 11 th of July 2020 , older adults accounted for $50.4 \%$ (96,582 individuals) of all COVID-19 cases $(191,466)$, with a higher proportion in age ranged 60-69 year $(20.1 \%)$. Also accounted for $71.8 \%$ of total deaths ( 68,842 individuals), with a higher proportion in the age ranged $70-79$ years $(24.8 \%)$ [3].

Among the symptoms, severe impairment of the lungs is a central factor associated with the severity of cases [4]. Other chronic diseases often present in the elderly, could also contribute to the higher mortality of this population [1]. In this scenario, a balanced and nutritious diet is one of the pillars to stay healthy, and adequate nutritional support could be the turning point in the patient's prognosis [5]. However, there are several situations during the pandemic that could compromise access to adequate nutrition due to social isolation, which is a necessary measure to contain the spread of COVID-19 [6]. In Figure 1 was summarize the mainly biological and environmental factors, and the possible management.

In Brazil, the Ministry of Health launched recommendations for older people, emphasizing the preference for meals prepared at home, reducing frequency of consuming meals from restaurants, coffee shops, or delivery services; preference for whole-grain foods, fruits, vegetables, rice, and beans for lunch and dinner (traditional Brazilian food habits); preference for low-fat and protein-rich foods (white meat and fish); reduction of fat, sugar, and salt intake; avoiding sweetened beverages and alcohol [11]. However, it can be challenging for many people to follow these recommendations during the pandemic. Especially in western countries and among older adults, the diet is often marked by a high energy density and low micronutrient content [14]. This aspect could be even more common during the quarantine period, when stress can pushes people toward overeating, mostly looking for more palatable foods rich in fat and sugar [15].

Nutrition professionals must track access to food, and if food insecurity is identified, appropriate guidance should be obtained from federal, state, or local resources to help meet the needs [6]. Moreover, individual and family counseling on healthy food choices and lists of essential supermarket food products [11]. Considering that many older adults may have difficulties in using digital media, it is necessary to know which media is most convenient for them to receive this information as well as strategies to improve health when necessary during quarantine [16]. The use of media, such as television and video-calls, to keep the older adults well informed about the COVID-19 situation and healthcare must be considered [12]. Thus, registered nutritionists and dietitians can offer remote nutritional follow-up sessions [6]. 


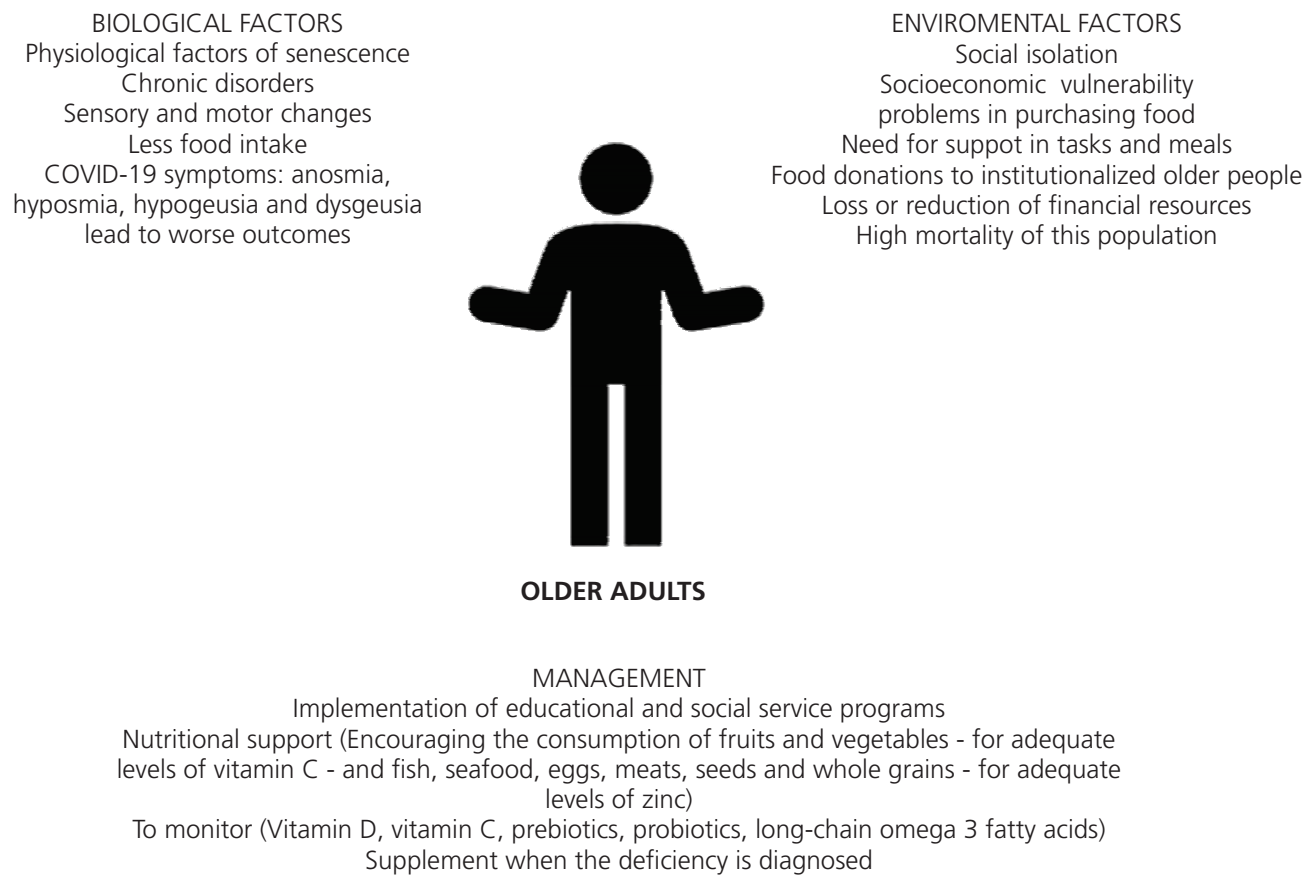

Figure 1. The main biological and environmental factors related to nutritional risk in older adults, and the management strategies during COVID-19 pandemic.

It has been demonstrated that older adults who eat meals in the company of others have better dietary quality $[17,18]$. Hence, the family and caregivers of these older adults should organize a schedule to be present during mealtimes using social media. Contact with family and trusted people through telephone and messages is also important, and it could help to reduce loneliness $[16,19]$.

Finally, government actions, such as the implementation of educational programs and social services, must be launched to promote health among older adults during pandemic [14]. Food supply actions should also be encouraged, such as the "Great Plates Delivered" program, an action implemented in California (United States) to supply three meals a day to seniors at risk for COVID-19. Among other requirements, the program provides delivery of balanced meals for older adults who live alone and are unable to prepare it or staying in a situation of food and nutritional insecurity [20].

\section{CONTRIBUTORS}

DK RIEGER, PF DI PIETRO, and JD MOREIRA were responsible for the conception, design, writing, review, and approval of the final version of this article. BC MENDES, J SCHOEDER, and G CEOLIN contributed to the conception, design, and writing of the manuscript.

\section{A C KNOWLEDGMENTS}

We would like to thank the Coordenação de Aperfeiçoamento de Pessoal de Nivel Superior (CAPES, Coordination for the Improvement of Higher Education Personnel). We would like also to thank the support of the Post Graduate Program in Nutrition at the Universidade Federal de Santa Catarina. 


\section{REFERE N CES}

1. Barazzoni R, Bischoff SC, Breda J, Wickramasinghe K, Krznaric Z, Nitzan D, et al. ESPEN expert statements and practical guidance for nutritional management of individuals with SARS-CoV-2 infection. Clin Nutr. 2020;39(6):1631-8. https://doi.org/10.1016/j.clnu.2020.03.022

2. Onder G, Rezza G, Brusaferro S. Case-fatality rate and characteristics of patients dying in relation to COVID-19 in Italy. J Am Med Assoc. 2020;323(18):1775-6. https://doi.org/10.1001/jama.2020.4683

3. Ministério da Saúde (Brasil). Boletim epidemiológico especial: doença pelo coronavirus Covid-19. Brasil: Secretaria de Vigilância em Saúde; 2020 [citado 19 jul 2020]. Disponível em: https://www.saude.gov.br/ images/pdf/2020/July/15/Boletim-epidemiologico-COVID-22.pdf

4. Román GC, Spencer PS, Reis J, Buguet A, Faris MEA, Katrak SM, et al. The neurology of COVID-19 revisited: a proposal from the Environmental Neurology Specialty Group of the World Federation of Neurology to implement international neurological registries. J Neurol Sci. 2020;414. https://doi.org/10.1016/j. jns.2020.116884

5. Jayawardena R, Sooriyaarachchi P, Chourdakis M, Jeewandara C, Ranasinghe P. Enhancing immunity in viral infections, with special emphasis on COVID-19: a review. Diabetes Metab Syndr. 2020;14(4):367-82. https:// doi.org/10.1016/j.dsx.2020.04.015

6. Handu D, Moloney L, Rozga M, Cheng F. Malnutrition care during the COVID-19 pandemic: considerations for registered Dietitian Nutritionists Evidence Analysis Center. J Acad Nutr Diet. 2020; [in press]. https://doi. org/10.1016/j.jand.2020.05.012

7. Mehta S. Nutritional status and COVID-19: an opportunity for lasting change? Clin Med. 2020;20(3):270-3. https://doi.org/10.7861/clinmed.2020-0187

8. Yoshimi K, Hara K, Tohara H, Nakane A, Nakagawa K, Yamaguchi K, et al. Relationship between swallowing muscles and trunk muscle mass in healthy elderly individuals: a cross-sectional study. Arch Gerontol Geriatr. 2018;79:21-6. https://doi.org/10.1016/j.archger.2018.07.018

9. Rech RS, Hugo FN, Tôrres LHN, Hilgert JB. Factors associated with hyposalivation and xerostomia in older persons in South Brazil. Gerodontology. 2019;36(4):338-44. https://doi.org/10.1111/ger.12415

10. Hara K, Tohara H, Kenichiro K, Yamaguchi K, Ariya C, Yoshimi K, et al. Association between tongue muscle strength and masticatory muscle strength. J Oral Rehabil. 2019;46(2):134-9. https://doi.org/10.1111/ joor. 12737

11. Ministério da Saúde (Brasil). Recomendações de alimentação para pessoas idosas no Brasil durante a pandemia de Covid-19. Brasília: Ministério; 2020 [citado 19 jul 2020]. Disponível em: http://docs.bvsalud. org/biblioref/2020/05/1096492/recomendacoes_alimentacao_pessoas_idosas_brasil_covid-19.pdf

12. Petretto DR, Pili R. Ageing and COVID-19: what is the role for elderly people? Geriatrics. 2020;5(2):1-4. https://doi.org/10.3390/geriatrics5020025

13. Aspell N, Laird E, Healy M, Shannon T, Lawlor B, O'Sullivan M. The prevalence and determinants of vitamin d status in community-dwelling older adults: results from the English Longitudinal Study of Ageing (ELSA). Nutrients. 2019;11(6):1253. https://doi.org/10.3390/nu11061253

14. Galli F, Reglero G, Bartolini D, Visioli F. Better prepare for the next one: lifestyle lessons from the COVID-19 pandemic. PharmaNutrition. 2020;12:100193. https://doi.org/10.1016/j.phanu.2020.100193

15. Yilmaz C, Gökmen V. Neuroactive compounds in foods: occurrence, mechanism and potential health effects. Food Res Int. 2020;128(108744):1-23. https://doi.org/10.1016/j.foodres.2019.108744

16. World Health Organization. Supporting older people during the COVID-19 pandemic is everyone's business. Copenhagen: Organization; 2020 [cited 2020 Jul 12]. Available from: https://www.euro.who.int/en/healthtopics/health-emergencies/coronavirus-covid-19/news/news/2020/4/supporting-older-people-during-thecovid-19-pandemic-is-everyones-business

17. Clegg ME, Williams EA. Optimizing nutrition in older people. Maturitas. 2018;112:34-8. https://doi. org/10.1016/j.maturitas.2018.04.001

18. Chae W, Ju YJ, Shin J, Jang S-I, Park E-C. Association between eating behaviour and diet quality: eating alone vs. eating with others. Nutr J. 2018;17(1):117. https://doi:10.1186/s12937-018-0424-0 
19. Newman MG, Zainal NH. The value of maintaining social connections for mental health in older people. The Lancet Public Health. 2020;5(1):e12-3. https://doi.org/10.1016/S2468-2667(19)30253-1

20. California State Government (United States). Great plates delivered: home meals for seniors: coronavirus COVID-19 response. Sacramento: California State Government; 2020 [cited 2020 Jul 12]. Available from: https://files.covid19.ca.gov/pdf/wp/great-plates-delivered-program-guidance.pdf

Receveid: June 62020

Final Version: July 212020

Approved: August 32020 